\title{
Is the era of bilateral internal thoracic artery grafting coming for diabetic patients? An updated meta-analysis
}

Pengyu Zhou, MD, ${ }^{a}$ Peng Zhu, MD, PhD, ${ }^{a}$ Zhiqiang Nie, MS, ${ }^{b}$ and Shaoyi Zheng, MD, $\mathrm{PhD}^{\mathrm{a}}$

\section{ABSTRACT}

Objective: Because of an increased risk of sternal wound complications, the use of bilateral internal thoracic artery grafting in diabetic patients remains controversial. The objective of the present meta-analysis is to compare the safety and efficacy of single internal thoracic artery and bilateral internal thoracic artery grafting in the diabetic population.

Methods: Four electronic databases, including PubMed, the Cochrane Library, Embase, and ISI Web of Knowledge, were comprehensively searched. Prospective randomized trials or observational studies comparing single internal thoracic artery and bilateral internal thoracic artery were considered eligible for the current study.

Results: A literature search yielded 1 randomized controlled trial and 17 observational studies (129,871 diabetic patients: 124,233 single internal thoracic arteries and 5638 bilateral internal thoracic arteries). Pooled analysis demonstrated overall incidence of deep sternal wound infection in the bilateral internal thoracic artery grafting group was significantly higher than in the single internal thoracic artery grafting group $(3.26 \%$ for bilateral internal thoracic artery vs $1.70 \%$ for single internal thoracic artery). No significant difference was found between both groups in terms of risk of deep sternal wound infection when the skeletonized harvesting technique was adopted. Furthermore, in-hospital mortality was comparable between both groups $(2.80 \%$ for bilateral internal thoracic artery vs $2.36 \%$ for single internal thoracic artery). However, compared with single internal thoracic artery grafting, bilateral internal thoracic artery grafting could confer a lower risk for long-term overall mortality (hazard ratio, 1.41; 95\% confidence interval, 1.18-1.67; $P<.001 ; \mathrm{I}^{2}=63 \%$ ) and cardiac mortality (hazard ratio, 3.15; 95\% confidence interval, 2.23-4.46; $P<.001 ; \mathrm{I}^{2}=0 \%$ ).

Conclusions: Compared with single internal thoracic artery grafting, bilateral internal thoracic artery grafting is associated with enhanced long-term survival among diabetic patients. Skeletonization of bilateral internal thoracic artery is not associated with an increased risk of deep sternal wound infection. Therefore, surgeons should be encouraged to adopt bilateral internal thoracic artery grafting in a skeletonized manner more routinely in diabetic patients. ( $\mathrm{J}$ Thorac Cardiovasc Surg 2019;158:1559-70)

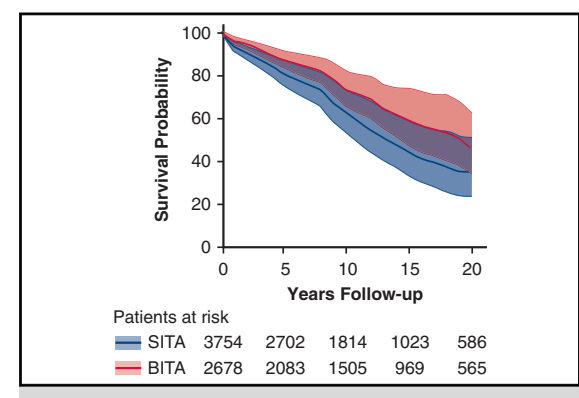

Aggregated overall Kaplan-Meier survival curves based on reconstructed and patient data.

\section{Central Message}

BITA grafting could increase long-term overal and cardiac mortality-free survival among the diabetic population.

\section{Perspective}

Because of an increased risk of sternal wound complications, the use of BITA grafting in diabetic patients remains controversial. This study suggests that for diabetic patients, BITA grafting could increase long-term overall and cardiac mortality-free survival, and skeletonization of BITA will not increase the risk of deep sternal would infection.

See Commentaries on pages 1571 and 1573.
During the last decade, some studies and guidelines have supported the superiority of coronary artery bypass grafting (CABG) over percutaneous therapy for diabetic patients with multivessel disease. ${ }^{1-3}$ Single internal thoracic artery

\footnotetext{
From the a Department of Cardiovascular Surgery, Nanfang Hospital, Southern Medical University, Guangzhou, Guangdong, People's Republic of China; and ${ }^{\mathrm{b}}$ Department of Epidemiology, Guangdong Cardiovascular Institute, Guangdong Provincial Key Laboratory of South China Structural Heart Disease, Guangdong General Hospital, Guangdong Academy of Medical Sciences, Guangzhou, Guangdong, People's Republic of China.

This research was supported by grants from Guangzhou Elites Scholarship Council (to P.Z).

This work was accepted as an oral presentation at the 4th Annual Meeting of International Coronary Congress, Beijing, China, August 2-5, 2018.
}

(SITA) has been regarded as an independent factor of improved survival for diabetic patients. ${ }^{4}$ However, bilateral internal thoracic artery (BITA) grafting is associated with improved survival and freedom from repeat revascularization

P.Z. and P.Z. contributed equally to this study.

Received for publication April 11,2018; revisions received Sept 4, 2018; accepted for publication Jan 21, 2019; available ahead of print April 2, 2019

Address for reprints: Shaoyi Zheng, MD, PhD, Department of Cardiovascular Surgery, Nanfang Hospital, Southern Medical University, No 1838 North Guangzhou Ave, Baiyun District, Guangzhou, People's Republic of China (E-mail: shaoyizheng@yahoo.com).

$0022-5223 / \$ 36.00$

Copyright (c) 2019 by The American Association for Thoracic Surgery

https://doi.org/10.1016/j.jtcvs.2019.01.129 


$$
\begin{aligned}
& \text { Abbreviations and Acronyms } \\
& \text { BITA }=\text { bilateral internal thoracic artery } \\
& \text { CABG }=\text { coronary artery bypass grafting } \\
& \text { CI }=\text { confidence interval } \\
& \text { DSWI }=\text { deep sternal wound infection } \\
& \text { HR }=\text { hazard ratio } \\
& \text { ITA }=\text { internal thoracic artery } \\
& \text { RR }=\text { risk ratio } \\
& \text { SITA }
\end{aligned}
$$

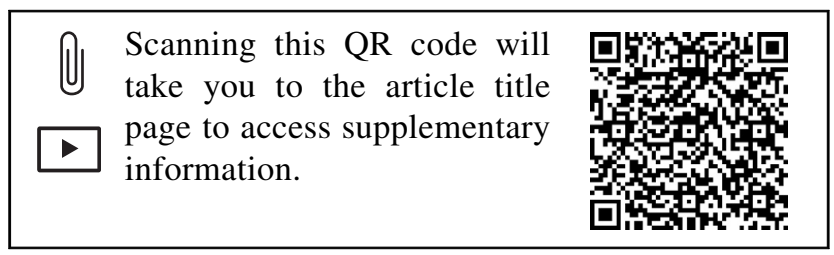

compared with SITA grafting in the general population. ${ }^{5}$ Unfortunately, despite the potential benefit of BITA grafting, the application of the BITA grafting technique in diabetic patients is controversial. The primary reason for avoiding the use of BITA is the increased risk of deep sternal wound infection (DSWI), which is particularly common among diabetic patients. ${ }^{6}$ BITA grafting with meticulous skeletonized technique of internal thoracic artery (ITA) harvesting is not associated with an increased risk of wound infection. ${ }^{7-9}$

A previous meta-analysis by Kajimoto and colleagues ${ }^{10}$ concluded that CABG using BITA grafts was an excellent strategy, even for diabetic patients. However, not all eligible studies, including some new observational studies, have been included in this meta-analysis. In addition, existing reviews, including a meta-analysis conducted by Deo, ${ }^{11}$ mainly focused on the incidence of DSWI, without a thorough analysis of long-term survival. Thus, this updated meta-analysis was conducted to compare short-term and long-term clinical outcomes of bilateral versus SITA grafting in diabetic patients.

\section{MATERIAL AND METHODS \\ Search Strategy}

A literature search was carried out by using PubMed, the Cochrane Library, Embase, and ISI Web of Knowledge of all related studies published between 1966 and January 2018. The search terms ("internal mammary artery" OR "internal thoracic artery") AND ("single" OR "unilateral") AND ("bilateral" OR "double") AND ("diabetes mellitus OR diabetics") were entered as keywords and MeSH terms.

\section{Eligibility Criteria}

Trials were selected on the basis of the following inclusion criteria: (1) studies comparing SITA and BITA grafting for diabetic patients; (2) patients enrolled in studies underwent isolated CABG, either on pump or off pump; and (3) studies providing postoperative DSWI, early mortality, or KaplanMeier curve for long-term overall survival or cardiac mortality-free survival.

\section{Study Selection}

Two researchers (P.Z. and P.Z.) independently screened all studies for inclusion. In duplicate, title and abstracts were screened, and then potentially eligible records in full text were retrieved for inclusion. Disagreements were resolved by discussion and consensus. Agreement between researchers regarding study inclusion was assessed using the Cohen $\mathrm{k}$ statistic.

\section{End Points and Their Definitions}

In most of the included studies, diabetic patients were diagnosed with diabetes mellitus according to the International Classification of Diseases, 10th Revision, with insulin or oral treatment before operation. The end points of this study were as follows: (1) DSWI; (2) early mortality; (3) Kaplan-Meier curve for long-term overall survival; and (4) Kaplan-Meier curve for longterm cardiac mortality-free survival. According to the guidelines of the Centers for Disease Control and Prevention, ${ }^{12}$ DSWI should consist of at least 1 of the following criteria: (1) isolation of an organism from culture of mediastinal tissue or fluid; (2) evidence of mediastinitis; and (3) chest instability or pain, sternal instability, or fever present in combination with purulent discharge from the mediastinum or an isolated organism from blood or tissue cultures. Early mortality included in-hospital or 30-day mortality. Long-term overall survival was defined as time from surgery to death from any causes. Long-term cardiac mortality-free survival was defined as time from surgery to death from cardiac-related events, including myocardial infarction, heart failure, and sudden death.

\section{Data Extraction and Quality Assessment}

Two researchers (P.Z. and P.Z.) independently extracted the following information from each study: lead author, publication year, participant characteristics, type of study, and number of grafts. Reviewers extracted the following outcomes: DSWI, early mortality, or Kaplan-Meier curve for long-term overall survival or cardiac mortality-free survival. Quality of included studies was assessed with the Newcastle-Ottawa scale for observational studies.

\section{Statistical Analysis}

This meta-analysis followed the Preferred Reporting Items for Systematic Review and Meta-Analysis guideline. ${ }^{13}$ For DSWI and early mortality, data regarding end points was used to generate risk ratios (RRs) and $95 \%$ confidence intervals (CIs). The $\mathrm{I}^{2}$-statistics were performed to test for heterogeneity between the included studies. Random-effect models were chosen over fixed-effect models because their assumptions accounted for the presences of variability among studies. Forest plots were then created for graphic presentation of clinical outcomes. To generate the pooled hazard ratio (HR) and 95\% CI for long-term mortality, first, Kaplan-Meier curves for long-term overall and cardiac mortality-free survival in each included study was digitalized in engauge digitizer software (version 10.4; maintained by Mark Mitchell). Second, log HR and corresponding standard error for each included study could be acquired with digitalized KaplanMeier curve data in the specific excel file provided by Tierney and colleagues. ${ }^{14}$ Finally, log HR and its corresponding standard error for each study could be combined in Review Manager (version 5.1.2; Cochrane Collaboration, Oxford, United Kingdom). With regard to aggregated Kaplan-Meier survival curves for long-term overall and cardiac mortality-free survival, digitalized Kaplan-Meier curve data, including Survival and NbRisk for each study, were aggregated to form combined survival curves in package MetaSurv of R software (version 3.4.3).

Subgroup analyses were performed for subsets of studies (propensitymatched cohorts and unmatched cohort) and for subsets of patients who underwent skeletonized ITA harvesting. Publication bias assessment was analyzed by funnel plots and evaluated by Egger's test and Begg's test. We assessed publication bias by examining funnel plots when the number of trials reporting the primary outcomes was 10 or more. Statistical analysis was conducted with Review Manager or R software. 
TABLE 1. Main characteristics of included studies

\begin{tabular}{|c|c|c|c|c|c|c|c|}
\hline Trials & $\begin{array}{c}\text { Patients } \\
\text { SITA/BITA (N) }\end{array}$ & $\begin{array}{l}\text { Study } \\
\text { period }\end{array}$ & $\begin{array}{c}\text { Length of } \\
\text { follow-up, } \\
\text { mean, } y\end{array}$ & $\begin{array}{c}\text { Skeletonized } \\
\text { SITA/BITA }(\%)\end{array}$ & Outcomes & $\begin{array}{c}\text { DM } \\
\text { SITA/BITA (\%) }\end{array}$ & Study design \\
\hline Endo $2003^{15}$ & $227 / 190$ & 1985-1998 & $8.1^{*}$ & $100 / 100$ & $\begin{array}{l}\text { DSWI, long-term all-cause } \\
\text { death, long-term cardiac } \\
\text { death }\end{array}$ & $100 / 100$ & Retrospective \\
\hline Hirotani $2003^{16}$ & $124 / 179$ & $1991-2003$ & NA & $0 / 0$ & $\begin{array}{l}\text { DSWI, in-hospital mortality, } \\
\text { long-term all-cause death, } \\
\text { long-term cardiac death }\end{array}$ & $100 / 100$ & Retrospective \\
\hline Lev-Ran $2003^{17}$ & $74 / 50$ & $1996-2001$ & $4.6^{*}$ & $100 / 100$ & $\begin{array}{l}\text { DSWI, 30-d mortality, long- } \\
\text { term all-cause death, long- } \\
\text { term cardiac death }\end{array}$ & $100 / 100$ & Retrospective \\
\hline Tavolacci $2003^{18}$ & $177 / 79$ & $1998-2000$ & NA & NA & DSWI & $100 / 100$ & Retrospective \\
\hline Dorman $2004^{19}$ & $414 / 414$ & 1972-1994 & 8.9 & $0 / 0$ & $\begin{array}{l}\text { DSWI, 30-d mortality, long- } \\
\text { term all-cause death }\end{array}$ & $100 / 100$ & $\begin{array}{l}\text { Propensity score } \\
\text { matched }\end{array}$ \\
\hline Lev-Ran $2004^{20}$ & $57 / 228$ & 1996-1998 & $5.0^{*}$ & $100 / 100$ & $\begin{array}{l}\text { DSWI, 30-d mortality, long- } \\
\text { term all-cause death, long- } \\
\text { term cardiac death }\end{array}$ & $100 / 100$ & Retrospective \\
\hline Stevens $2004^{21}$ & $419 / 214$ & $1985-1995$ & 11.0 & $0 / 0$ & $\begin{array}{l}\text { DSWI, 30-d mortality, in- } \\
\text { hospital mortality, long- } \\
\text { term all-cause death }\end{array}$ & $100 / 100$ & Retrospective \\
\hline Calafiore $2005^{9}$ & $200 / 200$ & $1991-2001$ & 6.0 & $84 / 85$ & $\begin{array}{l}\text { DSWI, in-hospital mortality, } \\
\text { long-term all-cause death, } \\
\text { long-term cardiac death }\end{array}$ & $100 / 100$ & $\begin{array}{l}\text { Propensity score } \\
\text { matched }\end{array}$ \\
\hline Momin $2005^{22}$ & $524 / 396$ & 1992-2002 & NA & $0 / 0$ & DSWI, 30-d mortality & $100 / 100$ & Retrospective \\
\hline Toumpoulis $2006^{23}$ & $490 / 490$ & 1992-2002 & 4.7 & NA & $\begin{array}{l}\text { DSWI, 30-d mortality, in- } \\
\text { hospital mortality, long- } \\
\text { term all-cause death }\end{array}$ & $100 / 100$ & $\begin{array}{l}\text { Propensity score } \\
\text { matched }\end{array}$ \\
\hline Savage $2007^{26}$ & $119,016 / 1732$ & 2002-2004 & NA & NA & DSWI, 30-d mortality & $100 / 100$ & Retrospective \\
\hline Agrifoglio $2008^{27}$ & $41 / 40$ & 2006 & 1.0 & $0 / 0$ & DSWI & $100 / 100$ & Retrospective \\
\hline Kinoshita $2010^{8}$ & $170 / 170$ & 2002-2009 & 3.2 & $100 / 100$ & $\begin{array}{l}\text { DSWI, 30-d mortality, long- } \\
\text { term all-cause death, long- } \\
\text { term cardiac death }\end{array}$ & $100 / 100$ & $\begin{array}{l}\text { Propensity score } \\
\text { matched }\end{array}$ \\
\hline $\begin{array}{l}\text { Konstanty- } \\
\quad \text { Kalandyk } 2012^{24}\end{array}$ & $109 / 38$ & 2006-2008 & 0.25 & $0 / 0$ & DSWI, 30-d mortality & $100 / 100$ & Retrospective \\
\hline Gansera $2016^{29}$ & $125 / 125$ & $2000-2011$ & 9.3 & NA & DSWI, 30-d mortality & $100 / 100$ & $\begin{array}{l}\text { Propensity score } \\
\text { matched }\end{array}$ \\
\hline Puskas $2012^{25}$ & $2715 / 812$ & $2002-2010$ & NA & NA & $\begin{array}{l}\text { DSWI, in-hospital death, } \\
\text { long-term all-cause death }\end{array}$ & $44.7 / 28.6$ & Retrospective \\
\hline Taggart $2012^{28}$ & $1554 / 1318$ & $1996-2010$ & 12.2 & NA & DSWI & $23.4 / 23.9$ & $\begin{array}{l}\text { Randomized } \\
\text { controlled trial }\end{array}$ \\
\hline Pevni $2017^{7}$ & $490 / 490$ & 2004-2007 & 1.0 & $100 / 100$ & $\begin{array}{l}\text { DSWI, in-hospital death, } \\
\text { long-term all-cause death }\end{array}$ & $100 / 100$ & $\begin{array}{l}\text { Propensity score } \\
\text { matched }\end{array}$ \\
\hline
\end{tabular}

SITA, Single internal thoracic artery; $B I T A$, bilateral internal thoracic artery; $N$, number of patients; $D M$, diabetes mellitus; $D S W I$, deep sternal wound infection; $N A$, not available *Length of follow-up, median, $\mathrm{y}$.

\section{RESULTS}

\section{Studies Retrieved and Characteristics}

A brief description of the results in present study can be seen in Video 1. A total of 323 potentially relevant studies were identified in the initial search (Figure E1, Preferred
Reporting Items for Systematic Reviews and MetaAnalyses diagram [Online Data Supplement 1]). After review, 18 studies, including 1 randomized controlled trial and 17 observational studies, ${ }^{7-9,15-29}$ were eligible for inclusion (Table 1). The $\mathrm{k}$ statistic for the final process of 
TABLE 2. Main characteristics of patients in included studies

\begin{tabular}{|c|c|c|c|c|c|}
\hline \multirow[b]{2}{*}{ Patient baseline } & \multirow{2}{*}{$\begin{array}{c}\text { No. of studies reporting } \\
\text { variables }\end{array}$} & \multicolumn{2}{|c|}{ Report No. of patients } & \multirow{2}{*}{$\begin{array}{c}\text { OR } / \text { mean difference, } \\
95 \% \mathrm{CI}\end{array}$} & \multirow[b]{2}{*}{$P$ value } \\
\hline & & SITA & $\overline{\text { BITA }}$ & & \\
\hline Mean age, $y$ & 14 & 121,940 & 4355 & $2.54[0.98-4.10]$ & $.001^{*}$ \\
\hline Female gender, $\mathrm{N}$ & 15 & 122,167 & 4545 & $1.42[1.14-1.77]$ & $.002 *$ \\
\hline BMI, mean (SD) & 7 & 119,991 & 2654 & $0.59[0.16-1.02]$ & $.007 *$ \\
\hline \multicolumn{6}{|l|}{ Preoperative characteristics } \\
\hline COPD, $\mathrm{N}$ & 9 & 121,043 & 3330 & $1.42[1.22-1.65]$ & $<.001^{*}$ \\
\hline HTN, N & 8 & 2241 & 1812 & $1.13[0.81-1.58]$ & .48 \\
\hline Renal impairment, $\mathrm{N}$ & 8 & 120,868 & 3360 & $1.66[1.18-2.33]$ & $.004^{*}$ \\
\hline Prior CVD, N & 7 & 1709 & 1656 & $1.46[0.66-3.24]$ & .35 \\
\hline Prior MI, N & 12 & 121,689 & 4226 & $1.08[0.94-1.24]$ & .30 \\
\hline \multicolumn{6}{|l|}{ Intraoperative characteristics } \\
\hline No. of grafts, mean (SD) & 10 & 2057 & 1854 & $-0.22[-0.35$ to -0.08$]$ & $.002 *$ \\
\hline $\mathrm{CPB}$, min & 5 & 1076 & 1222 & $-8.43[-22.37$ to 5.50$]$ & .24 \\
\hline Crossclamping time, min & 6 & 819 & 949 & $-5.97[-11.23$ to -0.71$]$ & $.03 *$ \\
\hline
\end{tabular}

$O R$, Odds ratio; $C I$, confidence interval; SITA, single internal thoracic artery; $B I T A$, bilateral internal thoracic artery; $N$, number of patients; $B M I$, body mass index; $S D$, standard deviation; $C O P D$, chronic obstructive pulmonary disease; $H T N$, hypertension; $C V D$, cerebrovascular disease; $M I$, myocardial infarction; $C P B$, cardiopulmonary bypass. *Statistically significant.

selection was 0.81 . Of these, all 18 studies $^{7-9,15-29}$ evaluated DSWI, 15 studies evaluated early mortality, ${ }^{7,15,17,19,26,29} 10$ studies evaluated long-term overall survival, $7,8,9,15,17,19,23,25$ and 4 studies evaluated long-term cardiac mortality-free survival. ${ }^{8,9,17,20}$ Propensity score-matched analysis was reported in 7 studies. $^{7-9,19,23,25,29}$ A skeletonized harvesting technique of ITA was adopted in 5 studies. ${ }^{7,8,15,17,20}$ Patient baseline, preoperative, and intraoperative characteristics are shown in Table E1. Definition and perioperative management of diabetes mellitus for each study are shown in Table 3. All of the confounders used in propensity score analysis are presented in Table 4.

TABLE 3. Definition and perioperative management of diabetes mellitus

\begin{tabular}{|c|c|c|c|c|c|c|}
\hline \multirow[b]{2}{*}{ Study } & \multirow{2}{*}{$\begin{array}{l}\text { Described } \\
\text { definition } \\
\text { of DM }\end{array}$} & \multicolumn{2}{|c|}{ Type of DM } & \multicolumn{2}{|c|}{ Treatment of DM before OP } & \multirow[b]{2}{*}{$\begin{array}{l}\text { Postoperative glucose } \\
\text { control protocol }\end{array}$} \\
\hline & & $\begin{array}{c}\text { SITA } \\
\text { (NIDDM/IDDM) }\end{array}$ & $\begin{array}{c}\text { BITA } \\
\text { (NIDDM/IDDM) }\end{array}$ & SITA & BITA & \\
\hline Endo $2003^{15}$ & Yes & NA & NA & $92^{*}, \dagger / 185 \ddagger$ & $80^{*}, \dagger / 110 \ddagger$ & NA \\
\hline Hirotani $2003^{16}$ & Yes & NA & NA & NA & NA & NA \\
\hline Lev-Ran $2003^{17}$ & Yes & NA & NA & $74^{*}$ & $50 *$ & Insulin treatment \\
\hline Tavolacci $2003^{18}$ & Yes & NA & NA & NA & NA & NA \\
\hline Dorman $2004^{19}$ & Yes & NA & NA & NA & NA & NA \\
\hline Lev-Ran $2004^{20}$ & Yes & NA & NA & $57 \ddagger$ & $228 \ddagger$ & Insulin treatment \\
\hline Stevens $2004^{21}$ & Yes & NA & NA & NA & NA & NA \\
\hline Calafiore $2005^{9}$ & Yes & NA & NA & $57 * / 143 \dagger$ & $49 * / 151 \dagger$ & Insulin treatment \\
\hline Momin $2005^{22}$ & Yes & NA & NA & $166 * / 255 \dagger$ & $95 * / 218 \dagger$ & NA \\
\hline Toumpoulis $2006^{23}$ & Yes & NA & NA & NA & NA & NA \\
\hline Savage $2007^{26}$ & NA & $83,772 / 35,289$ & $1320 / 412$ & NA & NA & NA \\
\hline Agrifoglio $2008^{27}$ & NA & $34 / 7$ & $34 / 6$ & NA & NA & Insulin treatment \\
\hline Kinoshita $2010^{8}$ & Yes & NA & NA & $85 * / 56+/ 30 \ddagger$ & $81 * / 59+/ 31 \ddagger$ & NA \\
\hline Konstanty-Kalandyk $2012^{24}$ & NA & NA & NA & $54 * / 55 \dagger$ & $23 * / 15 \dagger$ & Insulin treatment \\
\hline Gansera $2016^{29}$ & Yes & $75 / 50$ & $80 / 45$ & NA & NA & NA \\
\hline Puskas $2012^{25}$ & NA & NA & NA & NA & NA & NA \\
\hline Taggart $2012^{28}$ & NA & $284 / 79$ & $276 / 95$ & NA & NA & NA \\
\hline Pevni $2017^{7}$ & NA & $411 / 82$ & $424 / 63$ & NA & NA & NA \\
\hline
\end{tabular}

DM, Diabetes mellitus; SITA, single internal thoracic artery; NIDDM, noninsulin-dependent diabetes mellitus; IDDM, insulin-dependent diabetes mellitus; BITA, bilateral internal thoracic artery; $O P$, operation; $N A$, not available. *Insulin control. $\nmid$ Oral agent control. $\ddagger$ Diet control. 
TABLE 4. Description of confounders used in propensity score analysis studies

\begin{tabular}{|c|c|c|}
\hline Study & PSA methodology & Variables \\
\hline Dorman $2004^{19}$ & $\begin{array}{l}\text { 1:1 ratio using a Rosenbaum optimal } \\
\text { matching algorithm }\end{array}$ & $\begin{array}{l}\text { Age, cerebrovascular disease, CHF, dyslipidemia, impaired ejection fraction } \\
(<0.50) \text {, family history of coronary artery disease, hypertension, male gender, } \\
\text { PVD, prior MI, renal dysfunction, smoking history, 3-vessel disease, unstable } \\
\text { angina }\end{array}$ \\
\hline Calafiore $2005^{9}$ & $1: 1$ matching method not reported & $\begin{array}{l}\text { Age , female, diabetes mellitus on oral treatment, diabetes mellitus on insulin } \\
\text { treatment, urgent, extracardiac vasculopathy, preoperative acute MI, unstable } \\
\text { angina, CHF, chronic renal failure, COPD, ejection fraction, left main steam, } \\
\text { 2-vessel disease, 3-vessel disease, euroSCORE }\end{array}$ \\
\hline Toumpoulis $2006^{23}$ & $\begin{array}{l}1: 1 \text { ratio using logistic } \\
\text { regression analysis }\end{array}$ & $\begin{array}{l}\text { euroSCORE, age, female, race, vessels involved, unstable angina, previous MI } \\
\text { (most recent), transmural MI, }>1 \text { previous MI, previous cardiac operation, CCS } \\
\text { angina class, urgency operation, hemodynamic instability, shock, ejection } \\
\text { fraction categories, current CHF, past CHF, PVD, BMI categories, hypertension, } \\
\text { COPD, calcified aorta, renal failure, preoperative dialysis, hepatic failure, } \\
\text { immune deficiency, preoperative IABP, LV hypertrophy, malignant ventricular } \\
\text { arrhythmia, thrombolysis prior surgery, previous PCI, smoking previous year, } \\
\text { total bypass time, OPCABG, anastomoses }\end{array}$ \\
\hline Kinoshita $2010^{8}$ & $\begin{array}{l}\text { 1:1 ratio using multivariate logistic } \\
\text { regression model }\end{array}$ & $\begin{array}{l}\text { Age, female sex, body mass index, main fraction of glycosylated hemoglobin } \\
\text { (HgbA1C), PVD, COPD, previous MI, emergency operation, number of target } \\
\text { vessels, left main trunk having }>50 \% \text { stenosis, diagonal branch having }>75 \% \\
\text { stenosis, and circumflex artery having }>75 \% \text { stenosis }\end{array}$ \\
\hline Ganersa $2016^{29}$ & 1:1 matching method not reported & $\begin{array}{l}\text { Age, gender, number of grafts, elective, urgent/emergency operations, preoperative } \\
\text { infarction, } \mathrm{PCI} \text {, preoperative stent }\end{array}$ \\
\hline Pevni $2017^{7}$ & $\begin{array}{l}\text { 1:1 matching method using a saturated } \\
\text { logistic regression model }\end{array}$ & $\begin{array}{l}\text { Age, sex, insulin treatment, diabetes with end-organ damage, recent MI, chronic } \\
\text { renal failure, congestive heart failure, COPD, unstable angina, number of } \\
\text { diseased vessels, neurologic dysfunction, PCI, and ejection fraction } \leq 30 \%\end{array}$ \\
\hline
\end{tabular}

$P S A$, Propensity score analysis; $C H F$, congestive heart failure; $P V D$, peripheral vascular disease; $M I$, myocardial infarction; $C O P D$, chronic obstructive pulmonary disease; euro$S C O R E$, European System for Cardiac Operative Risk Evaluation; CCS, Canadian Cardiovascular Society; $B M I$, body mass index; IABP, intra-aortic balloon pump; $L V$, left ventricular; $O P C A B G$, off-pump coronary artery bypass grafting; $H g b A l C$, hemoglobin $\mathrm{A} 1 \mathrm{C}$; $P C I$, percutaneous coronary intervention.

\section{Quality Assessment}

The quality assessment of 17 observational studies are shown in Table 5. According to the Newcastle-Ottawa Scale for this meta-analysis (Table 6), all of these observational studies included scored between 7 and 9, indicating high methodologic quality.

\section{Deep Sternal Wound Infection}

In the Forest plots of DSWI shown in Figure 1, $A$, the overall incidence of DSWI in the BITA grafting group $(3.26 \%)$ was significantly higher than in the SITA grafting group $(1.70 \%)(\mathrm{RR}, 0.64 ; 95 \% \mathrm{CI}, 0.50-0.81 ; P<.001$; $\left.\mathrm{I}^{2}=12 \%\right)$. The incidence of DSWI in the BITA grafting group $(3.27 \%)$ was also significantly higher than in the SITA grafting group $(1.90 \%)(\mathrm{RR}, 0.60 ; 95 \% \mathrm{CI}, 0.41-$ $\left.0.87 ; P<.001 ; \mathrm{I}^{2}=0 \%\right)$ in the propensity-matched subgroup $^{5}$ studies in which skeletonized harvesting of the ITA grafts was performed were analyzed. As the Forest plots of DSWI show in Figure $1, B$, no significant difference was found between both groups in terms of risk of DSWI when the skeletonized harvesting technique was adopted (2.46\% for SITA group vs $2.48 \%$ for BITA group, RR, $0.94 ; 95 \%$ CI, $0.55-1.63, P=.84, \mathrm{I}^{2}=0 \%$ ). Subpopulation analysis also demonstrated that no significant difference was found between both groups in terms of risk of DSWI when the skeletonized harvesting technique was adopted (RR, 0.91; 95\% CI, 0.49-1.67, $P=.75, \mathrm{I}^{2}=0 \%$ ).

\section{Early Mortality}

Results of in-hospital and 30-day mortality are shown in Figure 2, A. Meta-analysis of the included studies showed that no significant difference was observed in early mortality between the BITA grafting group $(2.80 \%)$ and the SITA grafting group $(2.36 \%)(\mathrm{RR}, 1.16 ; 95 \% \mathrm{CI}, 0.94-1.42$, $\left.P=.17, \mathrm{I}^{2}=0 \%\right)$. Subpopulation analysis also demonstrated that no significant difference was observed in early mortality between both groups (RR, 1.21; 95\% CI, 0.87 $1.69, P=.26, \mathrm{I}^{2}=0 \%$ ).

\section{Long-Term Overall Survival}

Results of $\mathrm{HR}$ for long-term overall mortality are shown in Figure 2, B. Pooled analysis indicated BITA grafting had a lower risk for long-term overall mortality among diabetic patients when compared with SITA grafting (HR, 1.41; 95\% CI, 1.18-1.67, $P<.001, \mathrm{I}^{2}=63 \%$ ). The BITA cohort also demonstrated a lower risk for 
TABLE 5. Quality assessment of included observational studies using Newcastle-Ottawa Assessment Scale

\begin{tabular}{|c|c|c|c|c|c|c|c|c|c|}
\hline \multirow[b]{2}{*}{ Trials } & \multicolumn{4}{|c|}{ Selection } & \multirow[b]{2}{*}{ Comparability } & \multicolumn{4}{|c|}{ Outcome } \\
\hline & $\begin{array}{c}\text { Exposed } \\
\text { cohort }\end{array}$ & $\begin{array}{c}\text { Nonexposed } \\
\text { cohort }\end{array}$ & $\begin{array}{c}\text { Ascertainment } \\
\text { of exposure }\end{array}$ & $\begin{array}{c}\text { Outcome } \\
\text { of interest }\end{array}$ & & $\begin{array}{l}\text { Assessment } \\
\text { of outcome }\end{array}$ & $\begin{array}{l}\text { Length of } \\
\text { follow-up }\end{array}$ & $\begin{array}{l}\text { Adequacy } \\
\text { follow-up }\end{array}$ & $\begin{array}{l}\text { Total } \\
\text { score }\end{array}$ \\
\hline Endo $2003^{15}$ & $*$ & * & * & $*$ & $* *$ & $*$ & $*$ & $*$ & 9 \\
\hline Hirotani $2003^{16}$ & $*$ & $*$ & * & * & $* *$ & $*$ & $*$ & $*$ & 9 \\
\hline Lev-Ran $2003^{17}$ & $*$ & $*$ & * & $*$ & $* *$ & $*$ & $*$ & $*$ & 9 \\
\hline Tavolacci $2003^{18}$ & $*$ & $*$ & $*$ & * & & $*$ & $*$ & $*$ & 7 \\
\hline Dorman $2004^{19}$ & $*$ & $*$ & * & * & $* *$ & $*$ & $*$ & & 8 \\
\hline Lev-Ran $2004^{20}$ & $*$ & $*$ & $*$ & $*$ & $* *$ & $*$ & $*$ & $*$ & 9 \\
\hline Stevens $2004^{21}$ & $*$ & $*$ & $*$ & * & $* *$ & $*$ & $*$ & $*$ & 9 \\
\hline Calafiore $2005^{9}$ & $*$ & * & * & * & $* *$ & $*$ & * & $*$ & 9 \\
\hline Momin $2005^{22}$ & $*$ & $*$ & * & $*$ & $* *$ & $*$ & $*$ & $*$ & 9 \\
\hline Toumpoulis $2006^{23}$ & $*$ & $*$ & $*$ & * & $* *$ & $*$ & $*$ & & 8 \\
\hline Savage $2007^{26}$ & $*$ & $*$ & $*$ & * & $* *$ & $*$ & $*$ & $*$ & 9 \\
\hline Agrifoglio $2008^{27}$ & * & * & * & * & $* *$ & $*$ & $*$ & $*$ & 9 \\
\hline Kinoshita $2010^{8}$ & $*$ & $*$ & $*$ & * & $* *$ & $*$ & $*$ & $*$ & 9 \\
\hline Konstanty-Kalandyk $2012^{24}$ & $*$ & $*$ & * & * & $* *$ & $*$ & $*$ & $*$ & 9 \\
\hline Gansera $2016^{29}$ & $*$ & $*$ & $*$ & $*$ & $*$ & $*$ & * & * & 8 \\
\hline Puskas $2012^{25}$ & $*$ & * & * & * & $* *$ & $*$ & $*$ & & 8 \\
\hline Pevni $2017^{7}$ & $*$ & $*$ & $*$ & $*$ & $* *$ & $*$ & $*$ & $*$ & 9 \\
\hline
\end{tabular}

*1 point.

long-term overall mortality in the propensity-matched subgroup (HR, 1.34; 95\% CI, 1.08-1.67, $P<.001$, $\mathrm{I}^{2}=71 \%$ ). Reconstructed individual patient survival data from Kaplan-Meier survival curves of all 10 series demonstrated 1-year, 5-year, 10-year, 15-year, and 20 -year overall survivals at $94.33 \%, 81.31 \%, 63.30 \%$, $44.42 \%$, and $34.84 \%$, respectively, in the SITA arm and $96.70 \%, 87.83 \%, 73.71 \%, 59.42 \%$, and $46.43 \%$, respectively, in the BITA arm (Figure 3,C). KaplanMeier survival curves of all 5 propensity-matched studies demonstrated 1-year, 5-year, 10-year, 15-year, and 20 -year overall survivals at $92.98 \%, 78.20 \%, 59.10 \%$, $39.65 \%$, and $29.87 \%$, respectively, in the SITA arm and $95.14 \%, 85.98 \%, 67.00 \%, 42.93 \%$, and $31.48 \%$, respectively, in the BITA arm (Figure 3, B).

\section{Long-Term Cardiac Mortality-Free Survival}

As the Forest plots of HR for long-term cardiac mortality show in Figure 2, $C$, HR for long-term cardiac mortality significantly decreased in the BITA cohort compared with the SITA cohort (HR, 3.15; 95\% CI, 2.23-4.46, $P<.001$, $\mathrm{I}^{2}=0 \%$ ). Reconstructed individual patient survival data from Kaplan-Meier survival curves of all 4 series demonstrated 1-year, 3-year, 5-year, and 8-year cardiac mortality-free survival at $91.27 \%, 77.40 \%, 73.61 \%$, and $69.55 \%$, respectively, in the SITA arm and $98.42 \%$, $92.65 \%, 90.77 \%$, and $89.97 \%$, respectively, in the BITA arm (Figure 4).

\section{Publication Bias Assessment}

Neither the Begg rank correlation test $(P=.303)$ nor the Egger linear regression method $(P=.417)$ suggested publication bias was a significant factor when DSWI was selected as an end point. All 10 studies yield a Begg's test score of $P=.235$ and Egger's test score of $P=.698$ when assessing early mortality. However, evidence of publication bias was identified with long-term overall survival (Begg's $P=.032$; Egger's $P=.014$ ).

\section{DISCUSSION}

This present updated meta-analysis demonstrated that CABG with BITA grafting was not associated with an increased risk of DSWI in diabetic patients when the skeletonized harvesting technique was performed. Furthermore, BITA grafting offered comparable in-hospital mortality and provided long-term overall and cardiac mortality-free survival advantage compared with SITA grafting among diabetic patients.

Over the last decades, the excellent long-term survival of using BITA versus SITA is well established in several existing publications. In light of continuous accumulating evidence in favor of BITA grafting, the recent Clinical Practice Guideline by Society of Thoracic Surgeons recommended that a second skeletonized ITA should be used in patients who do not have an excessive risk of sternal complications (Classification of Recommendation IIa, Level of Evidence B). ${ }^{30}$ The present meta-analysis also 
TABLE 6. Newcastle-Ottawa quality assessment scale for cohort studies

Selection

1. Representativeness of the exposed cohort

a. truly representative of the average (describe) in the community*

b. somewhat representative of the average the community*

c. selected group of users, eg, nurses, volunteers

d. no description of the derivation of the cohort

2. Selection of the nonexposed cohort

a. drawn from the same community as the exposed cohort*

b. drawn from a different source

c. no description of the derivation of the nonexposed cohort

3. Ascertainment of exposure

a. secure record (eg, surgical records)*

b. structured interview*

c. written self-report

d. no description

4. Demonstration that outcome of interest was not present at start of study

a. yes*

b. no

Comparability

1. Comparability of cohorts on the basis of the design or analysis

a. study controls for at least 3 of the following 4 factors: age, sex, coronary anatomy, body mass index (select the most important factor)*

b. study controls for any additional comorbidities*

Outcome

1. Assessment of outcome

a. independent blind assessment

b. record linkage*

c. self-report

d. no description

2. Was follow-up long enough ( $>1 \mathrm{y}$, except those studies that only focus on in-hospital mortality and DSWI) for outcomes to occur

a. yes (select an adequate follow-up period for outcome of interest)*

b. no

3. Adequacy of follow-up of cohorts

a. complete follow-up, all subjects accounted for*

b. subjects lost to follow-up unlikely to introduce bias, small number lost, $\geq 95 \%$ (select an adequate $\%$ ) follow-up, or description provided of those lost)*

c. follow-up rate $<95 \%$ (select an adequate $\%$ ) and no description of those lost

d. no statement

A study can be awarded a maximum of 1 star for each numbered item within the Selection and Outcome categories. A maximum of 2 stars can be given for Comparability. DSWI, Deep sternal wound infection. *1 point.

demonstrated that BITA grafting significantly increased long-term overall and cardiac mortality-free survival among diabetic patients. However, on average, compared with the SITA cohort, patients allocated to the BITA cohort in this meta-analysis were younger, had less body mass index, and had lower prevalence of preoperative risks.

Therefore, these confounding factors and selection bias may result in better outcomes of BITA grafting. However, in our meta-analysis, propensity-matched subgroup analysis still presented the same findings, supporting favorable clinical outcomes of BITA grafting in more comparable cohorts.

Diabetes mellitus is a widely recognized risk factor for worse outcomes of patients with multivessel disease undergoing $\mathrm{CABG}$. The histologic and vasophysiologic properties of ITA are relatively protective against endothelial dysfunction, which is one of the important mechanisms underlying diabetes-related cardiovascular disease, and therefore result in favorable graft patency. ${ }^{31,32}$ These mechanisms may explain why BITA could offer better clinical outcomes compared with SITA for diabetic patients.

Although BITA grafting has been found to be associated with a lower risk for long-term mortality than SITA grafting in diabetic patients undergoing CABG, BITA grafting has not been routinely used. ${ }^{33}$ Indeed, clinical databases have shown that BITA grafting is used in only $4 \%$ of CABG surgeries in the United States $^{33}$ and $12 \%$ in Europe. ${ }^{34}$ Compared with SITA grafting, BITA grafting has several drawbacks, including the increased risk of DSWI especially for diabetic patients ${ }^{10}$ and longer preparation time and operative time, ${ }^{35}$ which may be seen as obstacles that could prevent widespread uptake of BITA grafting. In our present meta-analysis, BITA grafting was associated with a higher occurrence of DSWI than SITA grafting for diabetic patients both in the overall unmatched group and propensity-matched subgroup. BITA harvesting could exacerbate an acute postoperative devascularization of the sternum, and therefore increasing the risk of DSWI ${ }^{36}$ Although the incidence of DSWI among diabetic patients was relatively low in this present analysis $(1.70 \%$ for SITA group vs $3.26 \%$ for BITA group, $P=.0003$ ), DSWI has been recognized as a detrimental risk factor for long-term survival. $^{37}$

However, diabetic patients should not be entirely excluded from BITA grafting because of the increased risk of DSWI. Our data in the present meta-analysis showed that no significant difference was found between SITA grafting and BITA grafting in terms of risk of DSWI when the skeletonized harvesting technique was adopted. In comparison with the pedicled harvesting technique, the skeletonized technique preserves the collateral circulation to the sternum and the drainage of internal thoracic veins and thereby brings a lower risk of sternal infection. ${ }^{38}$

Preoperative control of glycosylated hemoglobin and postoperative glucose management are also critical to decrease the incidence of DSWI. Elevated preoperative glycosylated hemoglobin in patients presenting for CABG was 


\begin{tabular}{|c|c|c|c|c|c|c|c|c|c|}
\hline \multirow[b]{2}{*}{ Study or Subgroup } & \multicolumn{2}{|c|}{ SITA } & \multicolumn{2}{|c|}{ BITA } & \multirow[b]{2}{*}{ Weight } & Risk Ratio & \multirow{2}{*}{\multicolumn{2}{|c|}{$\begin{array}{c}\text { Risk Ratio } \\
\text { M-H, Random, } 95 \% \mathrm{CI}\end{array}$}} & \\
\hline & Events & Total & Events & Total & & M-H, Random, $95 \% \mathrm{Cl}$ & & & \\
\hline \multicolumn{10}{|c|}{ 1.1.1 UNMATCHED STUDIES } \\
\hline Agrifoglio 2008 & 0 & 41 & 0 & 40 & & Not estimable & & & \\
\hline Endo 2003 & 3 & 227 & 1 & 190 & $1.1 \%$ & $2.51[0.26,23.94]$ & & & \\
\hline Hirotani 2003 & 2 & 124 & 14 & 179 & $2.6 \%$ & $0.21[0.05,0.89]$ & & & \\
\hline Konstanty-Kalandyk 2012 & 8 & 109 & 2 & 38 & $2.5 \%$ & $1.39[0.31,6.28]$ & - & & \\
\hline Lev-Ran 2003 & 2 & 74 & 2 & 50 & $1.5 \%$ & $0.68[0.10,4.64]$ & & & \\
\hline Lev-Ran 2004 & 1 & 57 & 4 & 228 & $1.2 \%$ & $1.00[0.11,8.78]$ & & & \\
\hline Momin 2005 & 26 & 524 & 24 & 396 & $14.5 \%$ & $0.82[0.48,1.40]$ & $\longrightarrow$ & to & \\
\hline Puskas 2012 & 18 & 1213 & 4 & 232 & $4.6 \%$ & $0.86[0.29,2.52]$ & - & 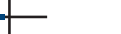 & \\
\hline Savage 2007 & 1969 & 119016 & 49 & 1732 & $30.4 \%$ & $0.58[0.44,0.77]$ & $=$ & & \\
\hline Stevens 2004 & 11 & 419 & 2 & 214 & $2.5 \%$ & $2.81[0.63,12.56]$ & -1 & & \\
\hline Tavolacci 2003 & 3 & 177 & 8 & 79 & $3.3 \%$ & $0.17[0.05,0.61]$ & - & & \\
\hline Subtotal $(95 \% \mathrm{Cl})$ & & 121981 & & 3378 & $64.2 \%$ & $0.69[0.46,1.05]$ & $\gamma$ & & \\
\hline Total events & 2043 & & 110 & & & & & & \\
\hline \multicolumn{10}{|c|}{ Heterogeneity: $\mathrm{Tau}^{2}=0.13 ; \mathrm{Chi}^{2}=14.25, \mathrm{df}=9(P=.11) ; \mathrm{I}^{2}=37 \%$} \\
\hline \multicolumn{10}{|c|}{ Test for overall effect: $Z=1.74(P=.08)$} \\
\hline \multicolumn{10}{|c|}{ 1.1.2 PROPENSITY MATCHED STUDIES } \\
\hline Calafiore 2005 & 3 & 200 & 6 & 200 & $2.9 \%$ & $0.50[0.13,1.97]$ & & - & \\
\hline Dorman 2004 & 7 & 414 & 13 & 414 & $6.2 \%$ & $0.54[0.22,1.34]$ & & - & \\
\hline Gansera 2016 & 3 & 125 & 4 & 125 & $2.6 \%$ & $0.75[0.17,3.28]$ & & & \\
\hline Kinoshita 2010 & 3 & 170 & 4 & 170 & $2.5 \%$ & $0.75[0.17,3.30]$ & & & \\
\hline Pevni 2017 & 16 & 490 & 17 & 490 & $10.4 \%$ & $0.94[0.48,1.84]$ & - & - & \\
\hline Toumpoulis 2006 & 6 & 490 & 16 & 490 & $6.0 \%$ & $0.38[0.15,0.95]$ & 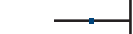 & & \\
\hline Subtotal $(95 \% \mathrm{Cl})$ & & 1889 & & 1889 & $30.7 \%$ & $0.64[0.43,0.97]$ & 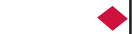 & & \\
\hline Total events & 38 & & 60 & & & & & & \\
\hline \multicolumn{10}{|c|}{ Heterogeneity: $\mathrm{Tau}^{2}=0.00 ; \mathrm{Chi}^{2}=2.90, \mathrm{df}=5(P=.72) ; \mathrm{I}^{2}=0 \%$} \\
\hline \multicolumn{10}{|c|}{ Test for overall effect: $Z=2.11(P=.03)$} \\
\hline \multicolumn{10}{|c|}{ 1.1.3 RANDOMIZED CONTROLL TRIAL } \\
\hline Taggart 2010 & 5 & 363 & 14 & 371 & $5.2 \%$ & $0.37[0.13,1.00]$ & & & \\
\hline Subtotal $(95 \% \mathrm{Cl})$ & & 363 & & 371 & $5.2 \%$ & $0.37[0.13,1.00]$ & & & \\
\hline Total events & 5 & & 14 & & & & & & \\
\hline \multicolumn{10}{|c|}{ Heterogeneity: Not applicable } \\
\hline \multicolumn{10}{|c|}{ Test for overall effect: $Z=1.95(P=.05)$} \\
\hline Total $(95 \% \mathrm{Cl})$ & & 124233 & & 5638 & $100.0 \%$ & $0.64[0.50,0.81]$ & $\diamond$ & & \\
\hline \multirow{2}{*}{\multicolumn{10}{|c|}{$\begin{array}{l}\text { Total events } \\
\text { Heterogeneity: } \mathrm{Tau}^{2}=0.03 ; \mathrm{Chi}^{2}=18.27, \mathrm{df}=16(P=.31) ; \mathrm{I}^{2}=12 \%\end{array}$}} \\
\hline & & & & & & & & & \\
\hline Test for overall effect: $Z=$ & $(P=.000$ & & & & & 0.01 & 0.1 & 10 & 100 \\
\hline Test for subgroup differenc & $\mathrm{Chi}^{2}=1.3$ & 2 & 2C) & $0 \%$ & & & SITA & BITA & \\
\hline
\end{tabular}

A

Test for subgroup differences: $\mathrm{Chi}^{2}=1.33, \mathrm{df}=2(P=.52), \mathrm{I}^{2}=0 \%$

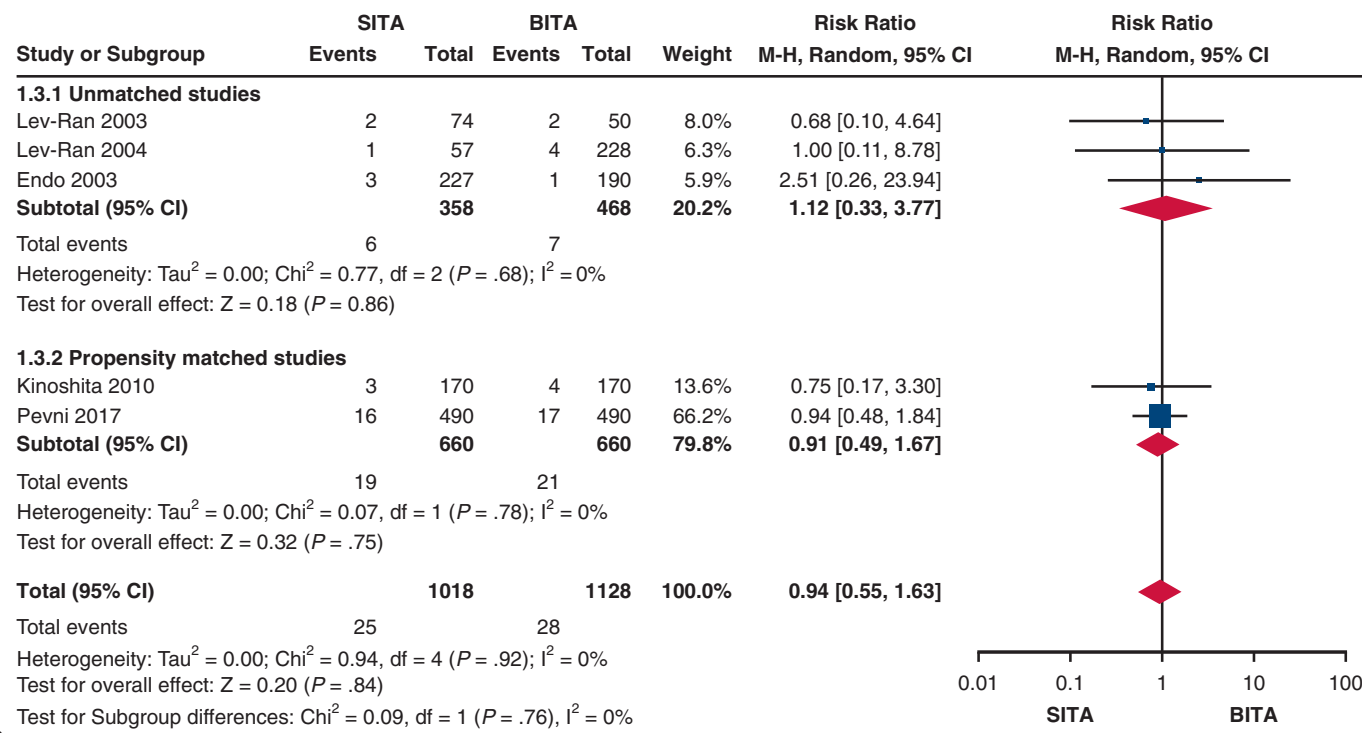

FIGURE 1. Forest plots of DSWI. A, Results of all 18 studies. B, Results of 5 studies in which ITA was harvested in a skeletonized fashion. Results are shown as RR with $95 \%$ CI. SITA, Single internal thoracic artery; $B I T A$, bilateral internal thoracic artery; $M$ - $H$, Mantel-Haenszel; $C I$, confidence interval; $d f$, degrees of freedom; $S E$, standard error; . 


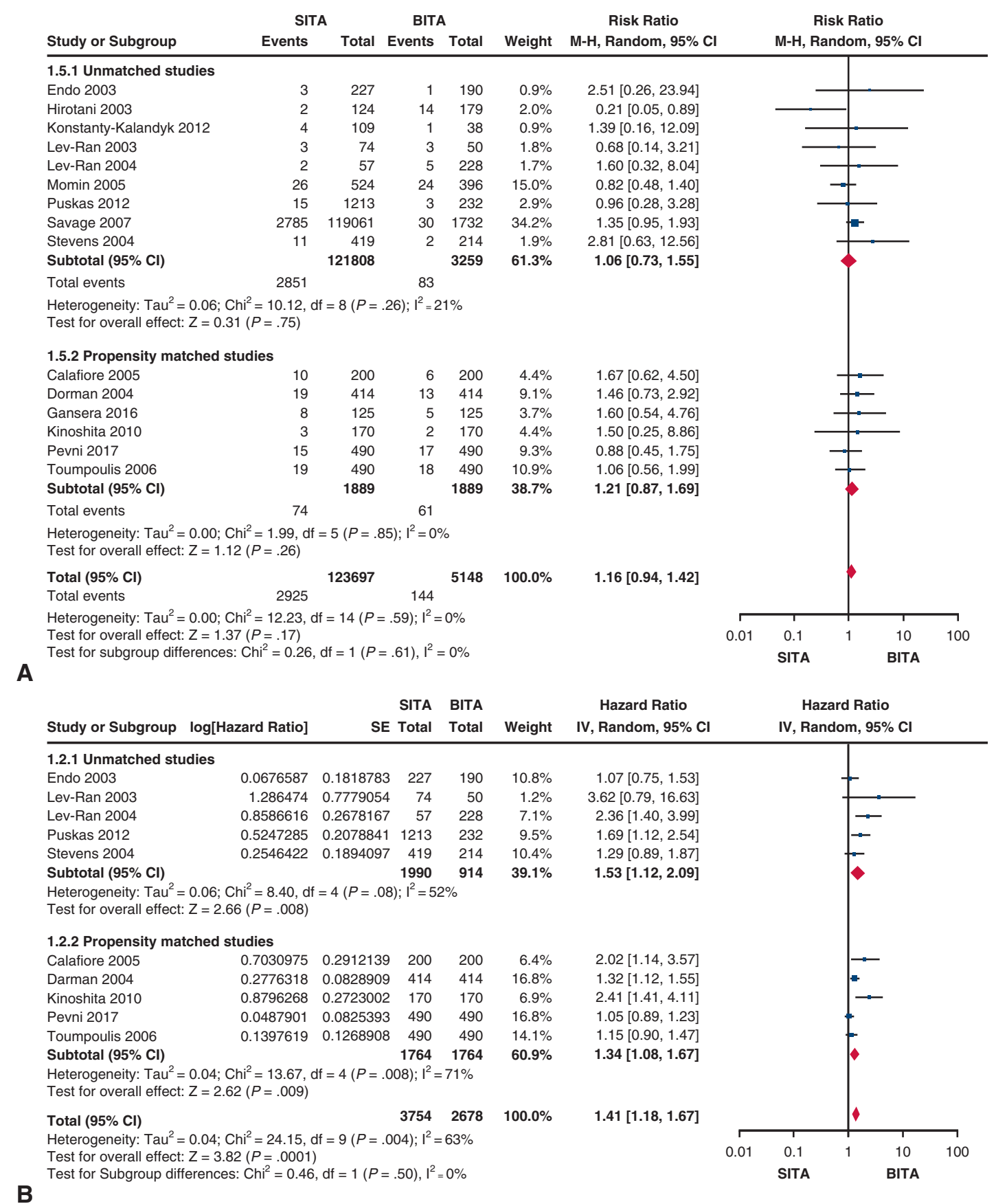

B

Study or Subgroup

Events Total Events Total Weight M-H, Random, 95\% C

-H, Random, 95\% Cl

1.5.1 Unmatched studies

Konstanty-Kalandyk 2012

Lev-Ran 2003

Total events

$\begin{array}{rr}3 & 227 \\ 2 & 124 \\ 4 & 109 \\ 3 & 74 \\ 2 & 57 \\ 26 & 524 \\ 15 & 1213 \\ 2785 & 11906 \\ 11 & 419 \\ & \mathbf{1 2 1 8 0 8}\end{array}$

The

$0.9 \%$

$0.21[0.05,0.89]$

$.39[0.16,12.09]$

$68[0.14,3.21]$

$1.35[0.95,1.93]$

$2.81[0.63,12.56]$

$1.06[0.73,1.55]$

1.5.2 Propensity matched studies

Subtotal $(95 \% \mathrm{Cl})$

Total events

99 ,

Test for overall effect: $Z=1.12(P=.26)$

125

490
1889

$(P=.85) ;\left.\right|^{2}=0 \%$

144

200

$10.9 \%$

$00.0 \%$

\section{Hazard Ratio}

1.2.1 Unmatched studies

Endo 2003

$\begin{array}{lll}0.8586616 & 0.2678167 & 57\end{array}$

$\begin{array}{lll}0.5247285 & 0.2078841 & 1213\end{array}$

$\begin{array}{rrr}0.5247285 & 0.2078841 & 1213 \\ 0.2546422 & 0.1894097 & 419\end{array}$

1990

Heterogeneity: $\mathrm{Tau}^{2}=0.06 ; \mathrm{Chi}^{2}=8.40, \mathrm{df}=4(P=.08) ; \mathrm{I}^{2}=52 \%$

Test for overall effect: $Z=2.66(P=.008)$

Darman 2004

Toumpoulis 200

$\begin{array}{llll}0.1397619 & 0.1268908 & 490 & 490\end{array}$

17); $I^{2}=71 \%$

$3754 \quad 2678 \quad 100.0 \%$

Heterogeneity: $\mathrm{Tau}^{2}=0.04 ; \mathrm{Chi}^{2}=24.15, \mathrm{df}=9(P=.004) ; \mathrm{I}^{2}=63 \%$

Test for overall effect: $Z=3.82(P=.0001)$

\begin{tabular}{|c|c|c|c|c|c|c|c|c|c|}
\hline \multirow{2}{*}{$\frac{\text { Study or Subgroup }}{\text { Calafiore } 2005}$} & log[Hazard Ratio] & \multirow{2}{*}{$\begin{array}{r}\text { SITA } \\
\text { Total } \\
200\end{array}$} & \multirow{2}{*}{$\begin{array}{r}\text { BITA } \\
\text { Total } \\
200\end{array}$} & \multirow{2}{*}{$\begin{array}{r}\text { Weight } \\
8.5 \%\end{array}$} & \multirow{2}{*}{$\begin{array}{c}\begin{array}{c}\text { Hazard Ratio } \\
\text { IV, Random, 95\% Cl }\end{array} \\
3.00[0.91,9.89]\end{array}$} & \multicolumn{4}{|c|}{$\begin{array}{c}\text { Hazard Ratio } \\
\text { IV, Random, } 95 \% \mathrm{CI}\end{array}$} \\
\hline & 1.0986120 .60838445 & & & & & & & & \\
\hline Kinoshita 2010 & 0.963174310 .33467541 & 170 & 170 & $28.0 \%$ & $2.62[1.36,5.05]$ & & & $\rightarrow-$ & \\
\hline Lev-Ran 2003 & $\begin{array}{lll}1.1600211 & 0.27749043\end{array}$ & 74 & 50 & $40.8 \%$ & $3.19[1.85,5.50]$ & & & $\rightarrow-$ & \\
\hline Lev-Ran 2004 & 1.3737160 .37169837 & 57 & 228 & $22.7 \%$ & $3.95[1.91,8.18]$ & & & $\rightarrow$ & \\
\hline Total $(95 \% \mathrm{Cl})$ & & 501 & 648 & $100.0 \%$ & $3.15[2.23,4.46]$ & & & $>$ & \\
\hline \multirow{2}{*}{\multicolumn{6}{|c|}{$\begin{array}{l}\text { Heterogeneity: } \mathrm{Tau}^{2}=0.00 ; \mathrm{Chi}^{2}=0.68, \mathrm{df}=3(P=.88) ; I^{2}=0 \% \\
\text { Test for overall effect: } \mathrm{Z}=6.48(P<.00001)\end{array}$}} & 0.01 & 0.1 & 10 & 100 \\
\hline & & & & & & & SITA & BITA & \\
\hline
\end{tabular}

FIGURE 2. Forest plots of mortality and survival. A, Results for early death. B, Results for HR of long-term overall mortality. C, Results for HR of longterm cardiac mortality. Results are shown as RR or HR with 95\% CI. SITA, Single internal thoracic artery; BITA, bilateral internal thoracic artery; $M-H$, Mantel-Haenszel; $C I$, confidence interval; $d f$, degrees of freedom; $S E$, standard error. 

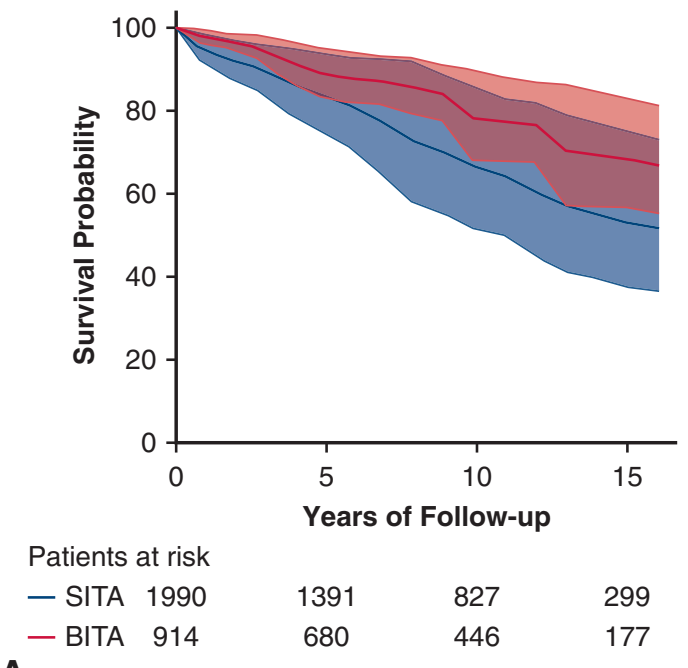

A

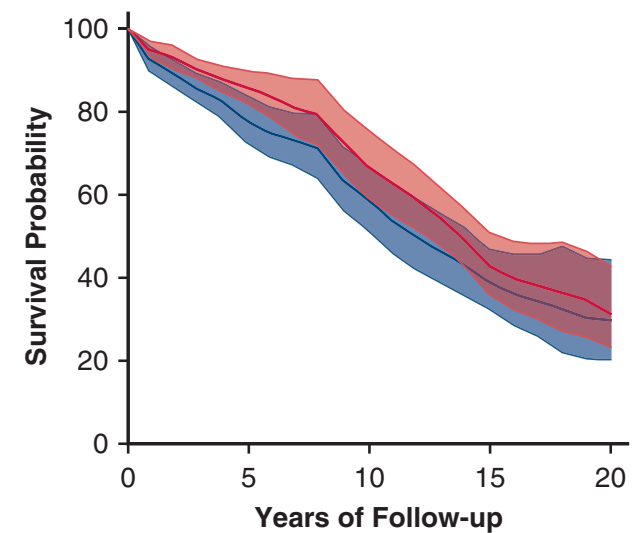

Patients at risk

$\begin{array}{llllll}- \text { SITA } & 1764 & 1250 & 802 & 474 & 240\end{array}$

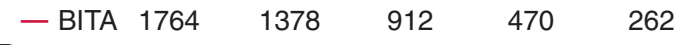

B

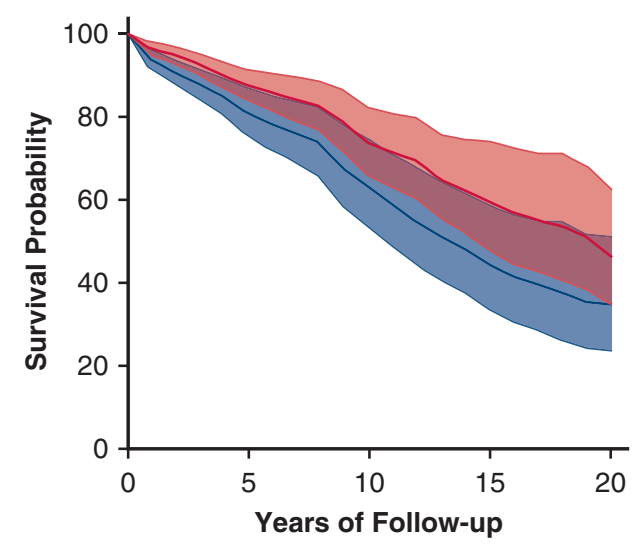

Patients at risk

$\begin{array}{llllll}\text { - SITA } & 3754 & 2702 & 1814 & 1023 & 586 \\ \text { - BITA } & 2678 & 2083 & 1505 & 969 & 565 \\ \text { C } & & & & & \end{array}$

FIGURE 3. Overall Kaplan-Meier survival curves based on reconstructed individual patient data. A, Aggregated survival curve for long-term overall survival with data of 1990 patients in SITA cohort and 914 patients in BITA cohort from 5 unmatched studies. B, Aggregated survival curve for long-

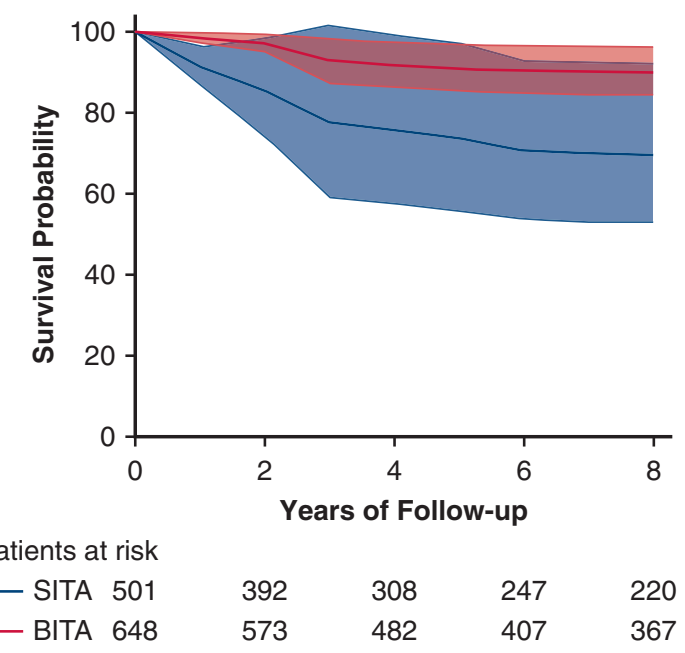

FIGURE 4. Aggregated survival curve for cardiac mortality-free survival with data of 501 patients in SITA cohort and 648 patients in BITA cohort from 4 studies. SITA, Single internal thoracic artery; BITA, bilateral internal thoracic artery.

associated with a significant increase in the incidence of DSWI. $^{39,40}$ In the present meta-analysis, 2 studies $^{8,27}$ recorded the data of HgbA1c before operation (Kinoshita and colleagues $^{8}: \quad 6.1 \% \pm 2.1 \%$ for SITA vs $6.3 \% \pm 2.4 \%$ for BITA; Agrifoglio and colleagues ${ }^{27}$ : $8.3 \% \pm 0.9 \%$ for SITA vs $8.6 \% \pm 1.0 \%$ for BITA). In addition, intensive glucose control was associated with a reduction of DSWI and mortality after CABG, as previously reported by Furnary and associates. ${ }^{41}$ In our metaanalysis, 5 studies ${ }^{9,17,20,24,27}$ described a specific protocol for postoperative glucose control, which was intensive glucose control by continuous insulin infusion, and similar incidences of DSWI between SITA and BITA cohort were reported.

\section{Study Limitations}

The results of the present meta-analysis were limited by several restraints and should be interpreted with caution. First, most of the included studies were retrospective analyses in nature, and some studies were not propensity score matched; therefore, intrinsic patient selection bias and significant confounding factors may affect the difference in observed outcomes. Second, variations in expertise and the rate of off-pump CABG of different centers could also account for clinical heterogeneity. Third, compared with SITA grafting, BITA grafting was typically preferred for

term overall survival with data of 1764 patients in SITA cohort and 1764 patients in BITA cohort from 5 matched studies. C, Aggregated survival curve for long-term overall survival with data of 3754 patients in SITA cohort and 2678 patients in BITA cohort from 10 studies. SITA, Single internal thoracic artery; BITA, bilateral internal thoracic artery. 


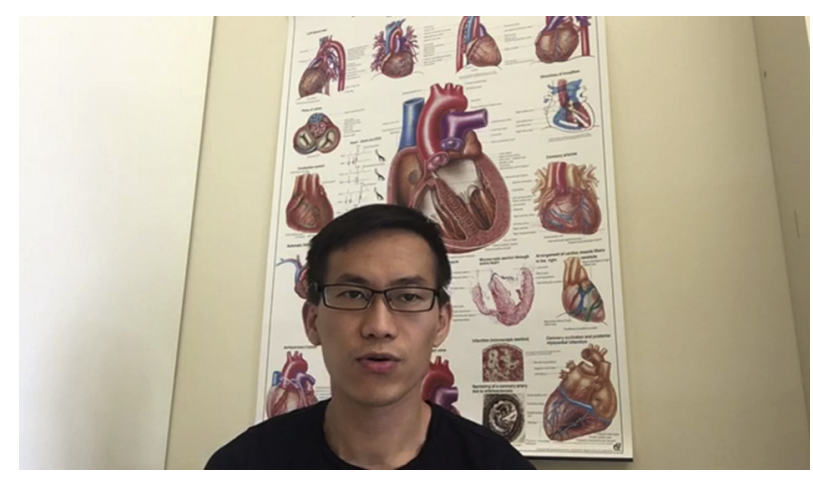

VIDEO 1. Pengyu Zhou, MD, presents the results of this study. Video available at: https://www.jtcvs.org/article/S0022-5223(19)30452-0/fulltext.

those with less preoperative risk profile, and therefore, it may naturally result in more favorable long-term survival in the BITA grafting group.

\section{CONCLUSIONS}

Compared with SITA grafting, BITA grafting increases the risk of DSWI in diabetic patients, although this is an infrequent risk. However, skeletonization of BITA is not associated with an increased risk of DSWI. Furthermore, BITA grafting is associated with superior overall late survival and increased cardiac mortality-free survival. In light of these findings, the long-term advantage of BITA outweighs its short-term risk. Therefore, surgeons should be encouraged to adopt BITA grafting in a skeletonized manner more routinely in diabetic patients.

\section{Conflict of Interest Statement}

Authors have nothing to disclose with regard to commercial support.

\section{References}

1. Bypass Angioplasty Revascularization Investigation (BARI) Investigators. Comparison of coronary bypass surgery with angioplasty in patients with multivessel disease. N Engl J Med. 1996;335:217-25.

2. Hillis LD, Smith PK, Anderson JL, Bittl JA, Bridges CR, Byrne JG, et al. 2011 ACCF/AHA guideline for coronary artery bypass graft surgery: a report of the American College of Cardiology Foundation/American Heart Association task force on practice guidelines. Circulation. 2011;124:e652-735.

3. Farkouh ME, Domanski M, Sleeper LA, Siami FS, Dangas G, Mack M, et al. Strategies for multivessel revascularization in patients with diabetes. $N$ Engl J Med. 2012;367:2375-84.

4. BARI Investigators. The final 10-year follow-up results from the BARI randomized trial. J Am Coll Cardiol. 2007;49:1600-6.

5. Taggart DP, D'Amico R, Altman DG. Effect of arterial revascularisation on survival: a systematic review of studies comparing bilateral and single internal mammary arteries. Lancet. 2001;358:870-5.

6. Mastrobuoni S, Gawad N, Price J, Chan V, Ruel M, Mesana TG, Rubens FD, et al. Use of bilateral internal thoracic artery during coronary artery bypass graft surgery in Canada: the bilateral internal thoracic artery survey. J Thorac Cardiovasc Surg. 2012;144:874-9.

7. Pevni D, Medalion B, Mohr R, Ben-Gal Y, Laub A, Nevo A, et al. Should bilateral internal thoracic artery grafting be used in patients with diabetes mellitus? Ann Thorac Surg. 2017;103:551-8.
8. Kinoshita T, Asai T, Nishimura O, Suzuki T, Kambara A, Matsubayashi K. Offpump bilateral versus single skeletonized internal thoracic artery grafting in patients with diabetes. Ann Thorac Surg. 2010;90:1173-9.

9. Calafiore AM, Di Mauro M, Di Giammarco G, Teodori G, Iacò AL, Mazzei V, et al. Single versus bilateral internal mammary artery for isolated first myocardial revascularization in multivessel disease: long-term clinical results in medically treated diabetic patients. Ann Thorac Surg. 2005;80:888-95.

10. Kajimoto K, Yamamoto T, Amano A. Coronary artery bypass revascularization using bilateral internal thoracic arteries in diabetic patients: a systematic review and meta-analysis. Ann Thorac Surg. 2015;99:1097-104.

11. Deo SV, Shah IK, Dunlay SM, Erwin PJ, Locker C, Altarabsheh SE, et al. Bilateral internal thoracic artery harvest and deep sternal wound infection in diabetic patients. Ann Thorac Surg. 2013;95:862-9.

12. Garner JS, Jarvis WR, Emori TG, Horan TC, Hughes JM. CDC definitions for nosocomial infections, 1988. Am J Infect Control. 1988;16:128-40.

13. Liberati A, Altman DG, Tetzlaff J, Mulrow C, Gøtzsche PC, Ioannidis JP, et al The PRISMA statement for reporting systematic reviews and meta-analyses of studies that evaluate health care interventions: explanation and elaboration. $J$ Clin Epidemiol. 2009;62:e1-34.

14. Tierney JF, Stewart LA, Ghersi D, Burdett S, Sydes MR. Practical methods for incorporating summary time-to-event data into meta-analysis. Trials. 2007;8:16

15. Endo M, Tomizawa Y, Nishida H. Bilateral versus unilateral internal mammary revascularization in patients with diabetes. Circulation. 2003;108:1343-9.

16. Hirotani T, Nakamichi T, Munakata M, Takeuchi S. Risks and benefits of bilateral internal thoracic artery grafting in diabetic patients. Ann Thorac Surg. 2003;76: 2017-22.

17. Lev-Ran O, Mohr R, Amir K, Matsa M, Nehser N, Locker C, et al. Bilateral internal thoracic artery grafting in insulin-treated diabetics: should it be avoided? Ann Thorac Surg. 2003; 75:1872-7.

18. Tavolacci MP, Merle V, Josset V, Bouchart F, Litzler PY, Tabley A, et al. Mediastinitis after coronary artery bypass graft surgery: influence of the mammary grafting for diabetic patients. J Hosp Infect. 2003;55:21-5.

19. Dorman MJ, Kurlansky PA, Traad EA, Galbut DL, Zucker M, Ebra G. Bilateral internal mammary artery grafting enhances survival in diabetic patients: a 30year follow-up of propensity score-matched cohorts. Circulation. 2012;126: 2935-42.

20. Lev-Ran O, Braunstein R, Nesher N, Ben-Gal Y, Bolotin G, Uretzky G, et al. Bilat eral versus single internal thoracic artery grafting in oral-treated diabetic subsets: comparative seven-year outcome analysis. Ann Thorac Surg. 2004;77:2039-45.

21. Stevens LM, Carrier M, Perrault LP, Hébert Y, Cartier R, Bouchard D. Influence of diabetes and bilateral internal thoracic artery grafts on long-term outcome for multivessel coronary artery bypass grafting. Eur J Cardiothorac Surg. 2005;27:281-8.

22. Momin AU, Deshpande R, Potts J, El-Gamel A, Marrinan MT, Omigie J, et al Incidence of sternal infection in diabetic patients undergoing bilateral internal thoracic artery grafting. Ann Thorac Surg. 2005;80:1765-72.

23. Toumpoulis IK, Anagnostopoulos CE, Balaram S. Does bilateral internal thoracic artery grafting increase long-term survival of diabetic patients? Ann Thorac Surg. 2006;81:599-607.

24. Konstanty-Kalandyk J, Piatek J, Rudzinski P, Wrobel K, Bartus K, Sadowski J Clinical outcome of arterial myocardial revascularization using bilateral interna thoracic arteries in diabetic patients: a single centre experience. Interact Cardiovasc Thorac Surg. 2012;15:979-83.

25. Puskas JD, Sadiq A, Vassiliades TA, Kilgo PD, Lattouf OM. Bilateral interna thoracic artery grafting is associated with significantly improved long-term survival, even among diabetic patients. Ann Thorac Surg. 2012;94:710-6.

26. Savage EB, Grab JD, O'Brien SM, Ali A, Okum EJ, Perez-Tamayo RA, et al. Use of both internal thoracic arteries in diabetic patients increases deep sternal wound infection. Ann Thorac Surg. 2007;83:1002-6.

27. Agrifoglio M, Trezzi M, Barili F, Dainese L, Cheema FH, Topkara VK, et al Double vs single internal thoracic artery harvesting in diabetic patients: role in perioperative infection rate. J Cardiothorac Surg. 2008;3:35.

28. Taggart DP, Altman DG, Gray AM, Lees B, Nugara F, Yu LM, et al. Randomized trial to compare bilateral vs. single internal mammary coronary artery bypass grafting: 1-year results of the arterial revascularisation trial (ART). Eur Heart J. 2010;31:2470-81.

29. Gansera B, Delalic A, Eszlari E, Eichinger W. 14-year results of bilateral versus single internal thoracic artery grafts for left-sided myocardial revascularization in young diabetic patients. Thorac Cardiovasc Surg. 2017;65:272-7.

30. Aldea GS, Bakaeen FG, Pal J, Fremes S, Head SJ, Sabik J, et al. The Society of Thoracic Surgeons clinical practice guidelines on arterial conduits for coronary artery bypass grafting. Ann Thorac Surg. 2016;101:801-9. 
31. Sabik JF III, Lytle BW, Blackstone EH, Houghtaling PL, Cosgrove DM. Comparison of saphenous vein and internal thoracic artery graft patency by coronary system. Ann Thorac Surg. 2005;79:544-51.

32. Fitzgibbon GM, Kafka HP, Leach AJ, Keon WJ, Hooper GD, Burton JR. Coronary bypass graft fate and patient outcome: angiographic follow-up of 5,065 grafts related to survival and reoperation in 1,388 patients during 25 years. $J$ Am Coll Cardiol. 1996;28:616-26.

33. Tabata M, Grab JD, Khalpey Z, Edwards FH, O'Brien SM, Cohn LH, et al Prevalence and variability of internal mammary artery graft use in contemporary multivessel coronary artery bypass graft surgery: analysis of the Society of Thoracic Surgeons national cardiac database. Circulation. 2009; 120:935-40.

34. Kappetein AP, Dawkins KD, Mohr FW, Morice MC, Mack MJ, Russell ME, et al. Current percutaneous coronary intervention and coronary artery bypass grafting practices for three-vessel and left main coronary artery disease. Insights from the SYNTAX run-in phase. Eur J Cardiothorac Surg. 2006;29:486-91.

35. Ioannidis JP, Galanos O, Katritsis D, Connery CP, Drossos GE, Swistel DG, et al Early mortality and morbidity of bilateral versus single internal thoracic artery revascularization: propensity and risk modeling. J Am Coll Cardiol. 2001;37: $521-8$.

36. Medalion B, Katz MG, Lorberboym M, Bder O, Schachner A, Cohen AJ. Decreased sternal vascularity after internal thoracic artery harvesting resolves with time: an assessment with single photon emission computed tomography. $J$ Thorac Cardiovasc Surg. 2002;123:508-11.

37. Toumpoulis IK, Anagnostopoulos CE, Derose JJ Jr, Swistel DG. The impact of deep sternal wound infection on long-term survival after coronary artery bypass grafting. Chest. 2005;127:464-71.

38. De Paulis R, de Notaris S, Scaffa R, et al. The effect of bilateral internal thoracic artery harvesting on superficial and deep sternal infection: the role of skeletonization. J Thorac Cardiovasc Surg. 2005;129:536-43.

39. Narayan P, Kshirsagar SN, Mandal CK, Ghorai PA, Rao YM, Das D, et al. Preoperative glycosylated hemoglobin: a risk factor for patients undergoing coronary artery bypass. Ann Thorac Surg. 2017;104:606-12.

40. Halkos ME, Thourani VH, Lattouf OM, Kilgo P, Guyton RA, Puskas JD, et al. Preoperative hemoglobin alc predicts sternal wound infection after coronary artery bypass surgery with bilateral versus single internal thoracic artery grafts. Innovations (Phila). 2008:3:131-8.

41. Furnary AP, Zerr KJ, Grunkemeier GL, Starr A. Continuous intravenous insulin infusion reduces the incidence of deep sternal wound infection in diabetic patients after cardiac surgical procedures. Ann Thorac Surg. 1999;67:352-62.

Key Words: bilateral internal thoracic artery grafting, coronary artery bypass grafting, diabetes, skeletonization 


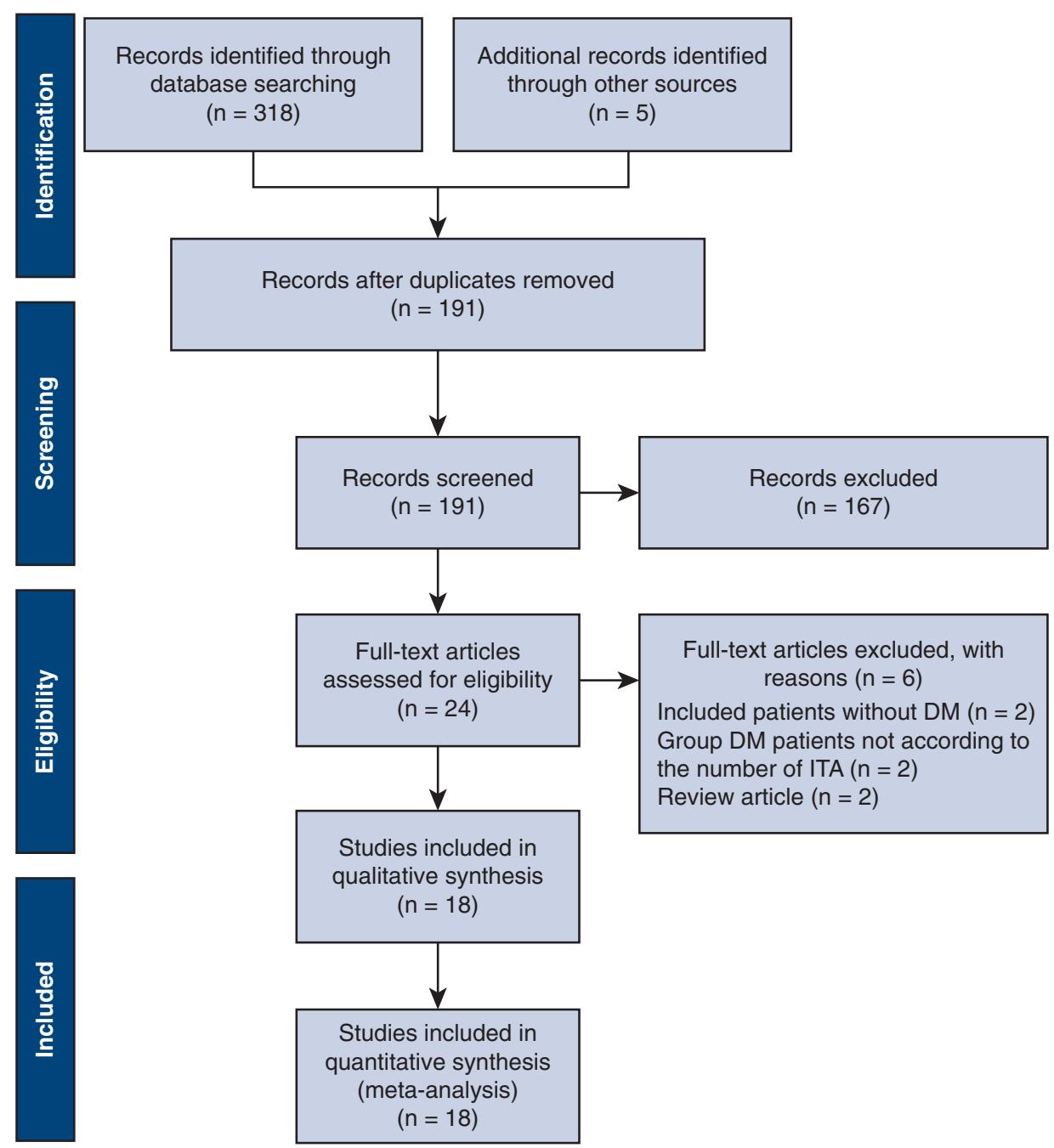

FIGURE E1. Preferred Reporting Items for Systematic Reviews and Meta-Analyses flow chart for literature search. DM, Diabetes mellitus; ITA, internal thoracic artery. 
TABLE E1. Main characteristics of patients in included studies

\begin{tabular}{|c|c|c|c|c|c|}
\hline \multirow[b]{2}{*}{ Patient baseline } & \multirow{2}{*}{$\begin{array}{c}\text { No. of studies reporting } \\
\text { variables }\end{array}$} & \multicolumn{2}{|c|}{ Report No. of patients } & \multirow{2}{*}{$\begin{array}{c}\text { OR/mean difference, } \\
95 \% \mathrm{CI}\end{array}$} & \multirow[b]{2}{*}{$P$ value } \\
\hline & & SITA & BITA & & \\
\hline Mean age, $\mathrm{y}$ & 14 & 121,940 & 4355 & $2.54[0.98-4.10]$ & $.001 *$ \\
\hline Female gender, $\mathrm{N}$ & 15 & 122,167 & 4545 & $1.42[1.14-1.77]$ & $.002 *$ \\
\hline BMI, mean (SD) & 7 & 119,991 & 2654 & $0.59[0.16-1.02]$ & $.007 *$ \\
\hline \multicolumn{6}{|l|}{ Preoperative characteristics } \\
\hline COPD, $\mathrm{N}$ & 9 & 121,043 & 3330 & $1.42[1.22-1.65]$ & $.001^{*}$ \\
\hline HTN, N & 8 & 2241 & 1812 & $1.13[0.81-1.58]$ & .48 \\
\hline Renal impairment, $\mathrm{N}$ & 8 & 120,868 & 3360 & $1.66[1.18-2.33]$ & $.004^{*}$ \\
\hline Prior CVD, N & 7 & 1709 & 1656 & $1.46[0.66-3.24]$ & .35 \\
\hline Prior MI, N & 12 & 121,689 & 4226 & $1.08[0.94-1.24]$ & .30 \\
\hline \multicolumn{6}{|l|}{ Intraoperative characteristics } \\
\hline No. of grafts, mean (SD) & 10 & 2057 & 1854 & $-0.22[-0.35$ to -0.08$]$ & $.002 *$ \\
\hline $\mathrm{CPB}, \min$ & 5 & 1076 & 1222 & $-8.43[-22.37$ to 5.50$]$ & .24 \\
\hline Crossclamping time, $\min$ & 6 & 819 & 949 & $-5.97[-11.23$ to -0.71$]$ & $.03^{*}$ \\
\hline
\end{tabular}

$O R$, Odds ratio; $C I$, confidence interval; SITA, single internal thoracic artery; $B I T A$, bilateral bilateral internal thoracic artery; $N$, number of patients; $B M I$, body mass index; $S D$, standard deviation; $C I$, confidence interval; $C O P D$, chronic obstructive pulmonary disease; $H T N$, hypertension; $C V D$, cerebrovascular disease; $M I$, myocardial infarction; $C P B$, cardiopulmonary bypass; $C V D$, cerebrovascular disease; $H T N$, hypertension; $M I$, myocardial infarction; $N$, number of patients, $O R$, odds ratio; $P V D$, peripheral vascular disease; $S D$, standard deviation; SITA, single internal thoracic artery. *Statistically significant. 